Robert JASTRZĘBSKI, DSc.

Faculty of Law and Administration, University of Warsaw

e-mail: r.jastrzebski@wpia.uw.edu.pl

DOI: $10.15290 /$ oes.2018.01.91.18

\title{
THE IMPACT OF THE ECONOMIC LEGISLATION ON THE RESTORATION OF THE POLISH STATE AFTER THE FIRST WORLD WAR
}

\begin{abstract}
Summary
The paper discusses the issue of the impact of Polish economic legislation on the restoration of the Polish State after the First World War. The author draws attention to those legal regulations that directly influenced the Polish legal order and constituted the result of the activity of the Polish legislature in the years 1918-1939. Most of those regulations were drafted by the Commission of Codification, which had been established under the Act of June 3,1919, and were related to two periods of economic reform: firstly - the reform conducted by Wladyslaw Grabski along with the earlier legislation mainly related to the period of partition of the Polish state; and secondly - the times after 1926. Significantly, an overwhelming number of regulations were promulgated in the form of decrees with the statutory validity issued by the President of the Second Republic of Poland, which actually eliminated the Polish Parliament from the legislative process. The purpose of these regulations was to unify economically the Polish lands and to create a uniform commercial law. It is worth emphasizing that such enactments as the Industrial Law of 1927, the Commercial Code, the Law of Arrangements with Creditors and the Insolvency Law (all enacted in 1934) remained in force also after 1945. Some of the aforementioned regulations, in particular the Commercial Code of 1934 that was finally repealed at the beginning of this century, largely affected the economic changes after 1989.
\end{abstract}

Key words: business law, commercial law, law codification, the Second Republic of Poland

\section{Introduction}

The development of economic legislation on the Polish lands took place during the First World War, when the countries responsible for Poland's partition were involved in military conflict. The term "economic law" dates back to the second half of the 19th century [Jastrzębski, 2015, pp. 50-53]. However, some historians derived the origins of the economic law from the French Revolution (1789) when the society was perceived as an independent factor in the country [Dniestrzański, 1932, p. 357]. The outbreak of the First World War resulted in the regulation of economic life by the countries involved in the war, which was the result of the so-called total war. Due to the situation, the state committed all the spheres of economic life to winning the world war. It was synonymous, among others, with the requisition of goods, food and industrial products in particular, the planning of economic life, the 
rationing of foreign currency and the circulation of money in the country, the introduction of both legislation combating loan sharks and residential legislation, i.e. anything that could guarantee winning the war that was taking place. However, after the end of World War I, the countries involved still had a similar impact on the economy, which was due to the post-war crisis. Due to this fact, it was believed that economic life constitutes the law of social administration, i.e. a phenomenon where economic factors exist in combination with social factors [Dniestrzański, 1932, p. 361].

It is worth emphasizing that in the period of the Second Republic of Poland the concept of economic law was frequently associated with the term "trade law" that was supposed to constitute the commercial superstructure of private law [Dziurzyński, Fenichel, Honzatko, 1935, p. 1]. Owing to this, "old-fashioned lawyers educated in accordance with the Roman law could not find a proper place for a economic law in the general system of law sciences", while others "were inclined to consider economic law as the extended commercial law". Furthermore, "those remaining under the impact of new ideas found in the economic law the already specified method of analyzing legislative norms regulating economic relations - the method where the analysis of economic and legislative norms are based on social phenomena which constitute the bases of these norms" [Janczewski, 1948, pp. 37-38]. The result of this was the limitation of liberal principles in economics that had existed before the outbreak of the World War I [Wrzos (in fact, H. Rosenberg), 1933, pp. 316-321]. On the other hand, liberalism was subject to certain limitations that aimed, among others, at changing the character of private ownership and economic freedom, with the state adopting the role of a producer, and at protecting national production [Rybarski, 1924, p. 259].

As a consequence, countries began to regulate various branches that had previously belonged to the private right, firstly in a legislative way, and later on in an administrative way. Owing to this, the economic law constituted the manifestation of state interventionism, which in Germany after World War I was defined as "the impact of the public hand" on the capitalist economy [Rosenblüth, 1928, p. 272]. Later on, due to the great economic crisis in the 1930s, the state became involved in economic life in a larger degree by means of legislative regulations, which resulted from the adopted economic strategy [Morawski, 2003, pp. 109-120].

In the case of the newly formed Polish state, it meant, above all, the replacement of the regulations introduced by the countries responsible for the partition of Poland by Polish regulations that were formed only within the frameworks of the adopted legislative activities. Therefore, the reasons for codification included above all the following factors:

1) political ones, related to the country's independence;

2) economic ones, regarding economic unification of the Polish lands that previously had belonged to the areas of other countries;

3) psychological ones, which resulted in the formation of a uniform state organism.

In the case of economic law, the first two reasons were most important. It regards chiefly the second factor which was initially related to the reform of 
economic life in the times of the treasury and currency reform and in subsequent years, as well as to the codification of Polish trade law - mainly in the early 1930s. The course and rate of legislative works were influenced by the principles of trade law, i.e. the principles of security, freedom and promptness [Namitkiewicz, 1927]. Therefore, the fast pace of legislative works as well as the political importance of the codification of Polish law were observed and discussed in 1921 by J. Piłsudski, who, during a conversation with F. Zoll in Cracow at the Mayor's cocktail party, claimed that in the Commission of Codification there were too many professors who strived for perfection and by doing so, inhibited the preparation of uniform codes. He claimed that "for Poland, the most important issue is the fastest possible unification of our private life. The codes may be less ideal, but they ought to be consistent as soon as it is possible", and that "we may try to make them perfect later on" [Wspomnienia Fryderyka Zolla, 2000, p. 473].

\section{Polish economic legislation (1918-1939)}

\subsection{The shaping period of the Polish state}

In Poland after World War I there were five legal systems as regards commercial (economic) law:

1) Napoleon's Commercial Code - the area of the Congress Kingdom of Poland [Babiński, Namitkiewicz, Ślaski, 1918];

2) Svod Zakonow, vol. XI, part II - the remaining area of the Russian partition [Ustawa Handlowa obowrazujaca na obszarze Wilenszcsyzny i Kresów W Schodnich - The Trade Contract Valid in the Vilnius region and Eastern Borderlands, 1927];

3) German Commercial Code - the Prussian district [Niemiecki kodeles handlony z.dnia 10. maja 1897 - The 10.05.1897 German Commercial Code, 1912];

4) Austrian commercial law based on German Commercial Code - the Austrian district [Ustawa Handlowa wraz. ₹. ustawami dodatkowemi - Commercial Act with additional acts, 1906, 1917];

5) Hungarian Commercial Code - Spisz, Orawa.

Hungarian law was replaced by the law that was in force in the area of the Appeals Court in Cracow, by virtue of the 14.09.1922 Cabinet Decree on the Organization of the Judiciary System in Spisz and Orawa, enabling some acts and decrees to be valid also in the area [The Journal of Laws, no. 90, item 833]. The decree was issued on the basis of the 26.10.1921 Act on Legislative regulations Binding in the Area of Spisz and Orawa Belonging to the Republic of Poland [The Journal of Laws, no. 89, item 657].

Owing to this, Poland in statu nascendi faced an important legislative task related to the codification and unification of the economic law, including a commercial law. Law codification of this aspect was task for the Codification Commission that was 
established on June, 3, 1919 by virtue of the Act on the Commission of Codification [The Journal of State Laws, no. 44, item 315] ${ }^{1}$. To start with, it is necessary to explain the meaning of the word 'codification'. In general, it implies the formation of uniform and regular entirety of legislative regulations from a certain law domain, which is combined with their amendment, simplification, supplementation and also cancellation of the regulations being in force so far. Unification, on the other hand, constitutes the harmonization (standardization) of law by introducing identical legislative regulations within the state. In the times of the Second Polish Republic these concepts were usually synonymous.

The Silesian district had special importance for the economic existence of that period and for the legislative system of Poland. Silesia was at the same time the smallest and least industrial district consisting of two former partition areas, i.e. Prussian and Austrian. The legal status of the area was regulated by the 15.07.1920 Constitution Act including the organic statute of the Silesian Voivodeship [The Journal of Laws, no. 73, item 497], which gave broad competencies to the local factors in terms of the functioning of the public and economic life in the district. In particular, there existed the Silesian Parliament that passed, among others, the budget of Silesian Voivodeship, taxes and local fees. It is worth emphasizing that Silesian acts did not require the approval of the President, the Seym of the Republic of Poland or any other authority. They were signed by the Marshal of the Silesian Parliament and conveyed to the voivode to be announced. Furthermore, the Silesian Parliament had so-called passive authorizations, i.e. the Parliament approved of the acts of the Seym of the Republic of Poland which mostly concerned economic law in the form of its original acts [Ciagwa, 1979, pp. 27-43].

The first regulations in the domain of economic law that aimed at uniforming this law domain were issued already by the Chief of State, Józef Piłsudski. They were related to the period of shaping the Polish state, and thus, they had the character of legal ephemeris. In fact, in the particular partition districts, the regulations of other countries were still in operation. The area of the former Congress Kingdom of Poland with the French Commercial Code being in force was of particular importance - it did not change considerably from the day it had come into force, i.e. from May, 1, 1809 [The 24.03.1809 Decree on the Adoption of the Commercial Code, the Journal of the Laws of the Duchy of Warsaw, vol. I, pp. 239-241]. Owing to this, the code was not compatible with the economic reality of that period [Namitkiewicz, 1921, pp. 425-438]. Therefore, the first legislative regulations concerning this area were issued rather early - in 1919. Namely, it was the 8.02.1919 Decree on Limited Liability Companies and the 7.02.1919 Decree on Commercial Register.

Furthermore, there were issued legal regulations regarding the entire area of Poland; these included, among others:

1 See further, among others the books: [Górnicki, 2000; Górnicki, 2015]. 
1) The 13.12.1918 Chief of State Decree on Temporary Patent Office [the Journal of the Acts of the Polish State, no. 21, item 66]; and interrelated decrees of the Chief of State of February, 4, 1919: on invention patents, on the protection of illustrated patterns and models, on the protection of trade marks [the Journal of the Laws of the Polish State, no. 13, items 137, 138, 139];

2) The 16.12.1918 Chief of State of Decree on Compulsory State Administration [the Journal of the Laws of the Polish State, no. 21, item 67];

3) The 23.03.1920 Act on Supervision of Bank Offices and Exchange Offices [the Journal of the Laws, no. 30, item 175];

4) The 29.10.1920 Act on Cooperatives [The Journal of Laws, no. 111, item 733];

5) The 20.01.1921 Act on Organization of a Stock Exchange in Poland [The Journal of Laws, no. 13, item 71].

The aforementioned regulations were drafted chiefly by the then executive authority and were meant to regulate temporarily the economic relations of the period, yet they were in force for a short period of time owing to the establishment of the Commission of Codification and the formation of the legislative authorities. Legal acts were written in a hurry, whereas the main changes in the economic situation of the state, which was facing more intensely the effects of increasing inflation, led to the situation where it was necessary to introduce modifications in the legislative methods and to introduce new regulations that unified the economic law on the Polish lands.

\subsection{Economic reform (related to the treasure and currency)}

On December, 19, 1923, the President of the Republic of Poland, Stanisław Wojciechowski elected Władysław Grabski as the Prime Minister and the Treasury Minister. He had already been the Prime Minister in 1920 and had been the Treasury Minister in the governments led by Leopold Skulski, Wincenty Witos, and Władysław Sikorski². Grabski's plan of economic sanction was based chiefly on:

1) the introduction of a property tax that was levied on groups with possessions and the introduction of tax valorization;

2) savings in expenditures; the elimination of subsidies, including those for railways; the reduction of national administration;

3) the organization of new treasure monopolies, which was supposed to result in the increase of budget revenues;

4) the powers granted by the Parliament that enabled decision-making in the issues related to reforms, by virtue of the statutory decrees issued by the President on the basis of Cabinet resolutions for a period of 6 months [Landau, Tomaszewski, 1971, pp. 185-193, Morawski, 2008, pp. 91-102].

2 See further: [Grabski, 1927]. 
The last case regards the 11.01.1924 Act on State Treasury Renovation and Currency Reform [Journal of Acts, no. 4, item 28] and the 31.01.1924 Act on State Treasury Renovation and Improvement of Social Administration [The Journal of Laws, no. 71, item 687], [Tomaszewski, 1961, pp. 45-47, 92-93]. On the basis of the last among the aforementioned acts, the deadline of issueing decrees by the President of the Republic of Poland was extended to December, 31, 1924 [Kraczkowski, 1994, pp. 124-131, 160-173]. In the first situation, the primary importance for monetary relations was assigned to the regulations regarding the following issues: the start-up of the emission bank, and, in particular, the 20.01.1924 Decree of the President of the Republic of Poland on the Establishment of the Emission Bank Statute [The Journal of Laws, no. 8, item 75], the 14.05.1924 Decree of the President of the Republic of Poland on the Miscalculation of Private and Legislative Obligations [The Journal of Laws, no. 42, item 441] ${ }^{3}$ and the 29.06.1924 Decree of the President of the Republic of Poland on the Monetary Usury [The Journal of Laws, no. 56, item 574]. Furthermore, regulations regarding the law of non-material goods were issued - the 5.02.1924 Act on the Protection of Inventions, Patterns and Trade Marks [The Journal of Laws, no. 31, item 306], which replaced the decrees from the years 1918-1919.

Yet, on the basis of the last statutory authorization there were issued the following decrees of the President of the Republic of Poland:

1) The 14.11.1924 Decree on the Bill of the Exchange Law [The Journal of Laws, no. 100, item 926];

2) The 14.11.1924 Decree on the Cheque Law [The Journal of Laws, no. 100, item 927];

3) The 10.12.1924 Decree on the Merger (connection) of Stock Companies and Limited Liability Companies [The Journal of Laws, no. 107, item 968];

4) The 27.12.1924 Decree on the Conditions of Performing Bank Operations and Supervision of These Activities [The Journal of Laws, no. 114, item 1018];

5) The 28.12.1924 Decree on the Organization of Stock Markets [The Journal of Laws, no. 114, item 1019; uniform text: The Journal of Laws of 1930, no. 23, item 209];

6) The 28.12.1924 Decree on the Law Regarding Warehouses [The Journal of Laws, no. 114, item 1020].

The purpose of these decrees was chiefly to enable the development of money circulation (also non-cash) and credit trading. Furthermore, they were supposed to lay down the framework for the operation of such institutions as banks, stock markets, warehouses. They were issued by the President of the Republic of Poland on the basis of Cabinet resolutions. In this way at that time the Parliament was "eliminated" from the legislative work. Naturally, the activities approved of by the then legislative authority aimed at accelerating the treasury and currency reform, i.e.

3 See further: [Jastrzębski, 2016]. 
the process of economic stability. Considerable importance was attached to the works of the Commission of Codification that elaborated on the projects of future decrees of the President of the Republic of Poland that regarded the bill of exchange law, cheque law and law regarding warehouses [Commission of Codification of the Republic of Poland), 1921, 1922]. Simultaneously, attention was drawn to the circulation of money surrogates, i.e. non-cash flow and circulation of bearer titles, whereas Jan Namitkiewicz explicite claimed that "if cheque became fully accepted in our country, as it is in England, we would not suffer from inflation and depreciation of our currency and we would not experience hard times connected with them!" [Namitkiewicz, 1925, p. 26].

On the other hand, in the case of the Decree on the Miscalculation of Private and Legal Obligations, the project of regulations was elaborated on by the special commission led by F. Zoll [Grabski, 1927, pp. 64-67; Jastrzębski, 2016, pp. 62-114]. In fact, the decree had the character of an indexation regulation, and its implementation was supposed to put an end to the credibilities in foreign currency and to the Polish brand. It implies that law codification and unification conducted at that time were related chiefly to currency reform, i.e. putting a new monetary unit into circulation.

\subsection{The period after 1926}

The subsequent stage of forming standardized economic legislation was the period following the May Coup in 1926 when the President of the Republic of Poland owing to the amendment of the 17.03.1921 Constitution, based on the 2.08.1926 Act that amended and supplemented the 17.03.1921 Constitution of the Republic of Poland (The Journal of Laws R.P., no. 44, item 267) [The Journal of Laws, no. 78, item 442] gained the possibility of issuing statutory decrees. On the basis of the decrees, there were issued numerous legal regulations, many of which were still in force after the end of the World War II. However, before the period of the so-called presidential decrees, Seym passed the 29.03.1926 Act on Copyright Law [The Journal of Laws, no. 48, item 286], the 2.08.1926 Act on Combating Unfair Competitiveness [The Journal of Laws, no. 96, item 559] and the 2.08.1926 Act on the Law Proper for Private Domestic Delations - Private Interregional Law [The Journal of Laws, no. 101, item 580]. The last of these regulations regarded the colliding laws related to the operation of various regulations of countries responsible for the partition of Poland in the area of Poland, including commercial law.

The statutory decrees regarding economic law include, among others:

1) The 7.06.1927 Decree of the President of the Republic of Poland on Industrial Law [The Journal of Laws, no. 53, item 468];

2) The 17.03.1928 Decree of the President of the Republic of Poland on Bank Law [The Journal of Laws, no. 34, item 321];

3) The 22.03.1928 Decree of the President of the Republic of Poland on the Protection of Inventions, Patterns and Trade Marks [The Journal of Laws, no. 39, item 384]; 
4) The 26.01.1928 Decree of the President of the Republic of Poland on the Control of Insurance [The Journal of Laws, no. 9, item 64];

5) The 29.11.1930 Decree of the President of the Republic of Poland on Mining Law [The Journal of Laws, no. 85, item 654].

The subsequent period of economic legislative system was related to a deep economic crisis that forced government members to issue legal regulations of a moratory character, which regarded in particular the farm debt restructuring legislation, including mortgage loans [Jastrzębski, 2009, pp. 266-318], and also anti-trust law - the 28.03.1933 Act on Cartels [Journal of Acts, no. 31, item 270] ${ }^{4}$. It resulted from the economic strategy adopted by Poland that was defined as a so-called deflationary policy [Knakiewicz, 1967, p. 26]. A considerable role was attached to the regulations related to the domestic and foreign currency and this was chiefly the so-called Dollar decree - the 12.06.1934 Decree of the President of the Republic of Poland on Credibility in Foreign Currencies [The Journal of Laws, no. 59, item 509] ${ }^{5}$ and the 26.04.1936 Decree of the President of the Republic of Poland on Money Circulation Abroad and the Circulation of Foreign and National Forms of Payment [The Journal of Laws, no. 32, item 249] ${ }^{6}$.

However, in this period, numerous regulations connected with the economic law were issued that had an impact on the Polish legal system, and consequently played a considerable role even after the end of the World War II, in particular after 1989. These were the regulations regarding mainly the codification of the commercial law and included, among others, the 22.03.1928 Decree of the President of the Republic of Poland on the Law of Stock-offering Companies [The Journal of Laws, no. 39, item 383] and the 27.10.1933 Decree of the President of the Republic of Poland on the Law of Limited Liability Companies [The Journal of Laws, no. 82, item 602]. However, the most important regulations from that period were the 27.06.1934 Decree of the President of the Republic of Poland - the Commercial Code [The Journal of Laws, no. 57, item 502] and the 27.06.1934 Interrelated Decree of the President of the Republic of Poland, the regulations introducing the Commercial Code [The Journal of Laws, no. 57, item 503] and the regulation regarding the commercial register - the 1.07.1934 Decree of the Minister of Justice issued in cooperation with the Minister of Industry and Commerce, and furthermore in terms of $\iint 5,8,55,62,65-69$ and 77 in cooperation with the Minister of Treasury, whereas in terms of $\iint 60$ and 64 in cooperation with the Ministers of Communication, Post Office and Telegraphs on Commercial Register [The Journal of Laws, no. 59, item 511]. However, earlier the 27.10.1933 Decree by the President of the Republic of Poland - the Code of Obligations [The Journal of Laws, no. 82, item 598] was issued. These regulations came into force on July, 1, 1934. Another group of decrees from that period were normalizations that regarded economic self-

See further: [Podolska - Meducka, Warsaw 2003].

See further: [Jastrzębski, 2014].

See further: [Landau, Tomaszewski, 1989]. 
government. They included the following decrees of the President of the Republic of Poland:

1) the 15.07.1927 Decree on Chambers of Commerce and Industry Journal of Laws, no. 67, item 591; uniform text: The Journal of Laws of 1936, no. 45, item 335];

2) the 22.03.1928 Decree on Chambers of Agriculture [Journal of Laws, no. 39, item 385; uniform text: The Journal of Laws of 1933, no. 2, item 16];

3) the 27.10.1933 Decree on Chambers of Crafts and Their Association [The Journal of Laws, no. 85, item 638], which was replaced by the 19.07.1939 Act on Chambers of Crafts and Their Association [The Journal of Laws, no. 65 , item 434].

Furthermore, in 1934 decrees on the bankruptcy law and arrangements law were issued. These were the 24.10.1934 Decrees of the President of the Republic of Poland on the Bankruptcy Law [The Journal of Laws, no. 93, item 834] and Arrangements Law [The Journal of Laws, no. 93, item 836]. What is important, due to the crisis of the 1930s, the arrangements conduct regarding farming, i.e. farm owners, was regulated separately. The regulations included chiefly the 23.08.1932 Decree of the President of the Republic of Poland on the Prevention of the Effects of Difficulties with Payment in Farming [The Journal of Laws, no. 72, item 652] and the 24.10.1934 Decree on the Conversion and Organization of Debts Related to Farming [The Journal of Laws, item 841]. These regulations were defined as farming anti-crisis legislation, whereas the issues related to debts incurred by farms were excluded from the jurisdiction of courts of common pleas Jastrzębski, 2009, pp. 271-308].

In the Polish legal system the regulations in economic law that were issued in the mid-1930s and were abolished after the end of II World War are defined as the regulations with the longest history. Namely, it regards the commercial code, the code of obligations and also the bankruptcy conduct and arrangement law. These regulations were in force after 1945 and some of them after 1989. In the last case, the abrogation of the commercial code was chiefly related to the fact that on January, 1, 2001, the 15.09.2000 Act came into force. There were also introduced: the code of commercial companies [The Journal of Laws, no. 94, item 1037], the bankruptcy law and arrangement law when the 28.02.2003 Act came into force on October, 1, 2003 - it regarded the bankruptcy and reorganization law [The Journal of Laws, no. 60, item 535]. On the other hand, the Decree of the President of the Republic of Poland on Industrial Law from 1927 was in force till January, 1, 1973, when it was finally abrogated by the 8.06 .1972 Act on Performance and Organization of Crafts [The Journal of Laws, no. 23, item 164], whereas the subsequent regulation regarding economic activity was the 23.12.1988 Act on Economic Activity [The Journal of Laws, no. 41, item 324]. Furthermore, the existing economic self-government after 1945 functioned only in a residual form, in the form of crafts, the operation of which was regulated by: the 11.09.1956 Act on Chambers of Crafts and the Association of Chambers of Crafts [The Journal of Laws, no. 41, item 190]; the 8.06.1972 Act on Performance and Organization of Craft Journal of 
Law, no. 23, item 164; uniform text: The Journal of Laws, no. 7, item 40]; the 22.03.1989 on Craft [The Journal of Laws, no. 17, item 92]. Chambers of commerce and industry as well as chambers of agriculture, on the other hand, ceased to function in the late 1950s, on the basis of the 7.03.1950 Act on Central Office of Small-Scale Production [The Journal of Laws, no. 10, item 104], the 26.08.1946 Decree on the Abolition of Chamber of Agriculture (The Journal of Laws, no. 47, item 265) and the 1.07.1949 Act on the Change of the Decree on the Abolition of Chamber of Agriculture (The Journal of Laws, no. 41, item 296), yet their "reactivation" took place after the political, social and economic changes at the turn of the 1980s and 1990s. Namely, it regarded the activity of chambers of commerce functioning on the basis of the 30.05.1989 Act on the Chambers of Commerce [The Journal of Laws, no. 35, item 195] and farming chambers that function on the basis of the 14.12.1995 Act on Farming Chambers [The Journal of Laws, no. 1996 r. no. 1 , item 3].

\section{Conclusion}

To conclude, it is necessary to emphasize the fact that economic union in a way constituted the introduction to the political union of a one state organism. The Uniform economic legislation facilitates and removes differences in terms of the status of economic entities and legal relations. In history there are numerous examples of such economic and legal phenomena, one example of which was the $19^{\text {th }}$ century when German states established the Customs Union in 1834, and then formed uniform legal frameworks for economic return, e.g. at the conference in Leipzig in 1847, a uniform project of the bill of exchange law was proposed, which was later adopted by particular German states in the years 1848 - 50 [Jastrzębski, 2003, p. 16].

The impact of the economic legislation on the restoration of the Polish state after the end of the World War I was considerable. It is worth emphasizing that uniform economic law always petrifies the economic life of a newly established state, including the Second Republic of Poland. Naturally, the law established in that period/at that time was influenced by earlier regulations that were binding on the Polish lands, especially the ones from the area of Galicja - the Austrian partition. It resulted chiefly from the existence of the university centers in Cracow and Lviv which functioned within the frameworks of the so-called Galicja Autonomy. The main creators of the Polish projects of economic norms came from that area. They included, among others, Stanisław Wróblewski, Aleksander Doliński, Maurycy Allerhand, Tadeusz Dziurzyński, Antoni Górski and Fryderyk Zoll [Górnicki, 2003].

Obviously, in the Second Republic of Poland at that time there occurred tendencies to expand the omnipotence of the state. It resulted in the development of legislation, not only in terms of economic law. It needs emphasizing that the conducted codification of the economic law was not complete. An example is the commercial code that constituted the first part of the code. It was supposed to be supplemented by the law regarding seas and lakes and also the private insurance law. 
Legislative works related to economic law took place during two major periods - i.e. during W. Grabski's treasury and currency reform and the period following the May Coup. In the last case, the legislation of the first half of the 1930s which was still in force for numerous years after the end of World War II may be mentioned.

However, it is worth emphasizing that the economic regulations from that period had chiefly the character of decrees issued by the President of the Republic of Poland. This situation resulted from the fact that the creation of economic directives was a task entrusted to a small group of people - specialists. Additionally, a crucial factor that influenced the legislative and actual success of the new directives was time. Owing to a long legislative process, the Parliament could not guarantee fast changes in the legislative and economic system. Therefore, the legislative functions were assigned to the then executive through using the works of the Codification Commission and its own body of legislation for this purpose. In particular, a special role was played by the projects of the Codification Commission that concerned, among others, the commercial code, the bill of the exchange law, the cheque law as well as the law regarding warehouses, the bankruptcy and restoration law or the industrial law. It needs emphasizing that other sections of law, when compared with widely understood commercial law, were not codified to such a degree before the outbreak of World War II.

The restoration of the Polish state also contributed to the fact that it was necessary to issue a number of economic regulations that aimed at blurring the differences between legislative systems of particular districts of Poland, which was supposed to uniform the economic turnover within the frameworks of one constitutional body. However, it is worth emphasizing that although the economic law was not subject to complete codification and unification, the legislative regulations from the times of the Second Republic of Poland influenced and will still have an impact on the contemporary system of Polish law, e.g. the bill of the exchange law and the cheque law from 1936, which are based on Geneva conventions from the years $1930-31$, are still in force ${ }^{7}$. This example shows that the economic legislative system of the Second Republic of Poland played a crucial role not only in the unification of the Polish lands after World War I, i.e. in in statu nascendi of the Polish state, but also after 1945. Hardly anyone is aware that taking ownership of industrial plants before the 3.01.1946 Act came into force (on Taking the Ownership of Basic National Industry Branches by the State) [The Journal of Laws, no. 3, item 17] took place on the basis of the 16.12.1918 Chief of State Decree on the Compulsory State Administration [The Journal of Laws of the Polish State, no. 21, item 67] which was abolished by the 25.02.1958 Act on Regulating the Legal Status of the Possessions Remaining Under State Administration [The Journal of Laws, no. 11, item 37].

A number of acts and decrees signed by the President of the Republic of Poland in the 1930s, and in particular those from the field of commercial law contributed to ownership changes after 1989. Due to the fact that the economic legislative system

7 See further: [Jastrzębski, Warsaw, 2010]. 
creates one economic organism, it may later on transform into homogenous legal and political system. It took place in the times of the Second Polish Republic when the formed legal regulations were so permanent that they could be used after the change of the political and economic system in the late 1980s. Owing to this, the economic legislative system of Poland in the years 1918-1939 not only had an impact on the creation of the legally uniform economic sphere, but also contributed to the further development of the Polish state after 1945.

\section{References}

Babiński L., Namitkiewicz J., Ślaski B., 1918, Kodeks Handlowy obowiqzujacy w Królestwie Polskiem. Nowy przektad Polski wraz z jurysprudencya, wyd. z zapomogi Kupiectwa m.st. Warszawy, Warsaw.

Ciagwa J., 1979, Wplyw centralnych organón Drugiej Rzecsypospolitej na ustawodawstwo ślaskie w latach 1922-1939, Prace Naukowe Uniwersytetu Ślaskiego, Katowice.

Dekret Naczelnika Państwa z dnia 13 grudnia 1918 r. o tymczasowym Urzędzie Patentowym, Dz. Praw Państwa Polskiego nr 21, poz. 66 (The 13.12.1918 Chief on State Decree on Temporary Patent Office, Journal of Law of the Polish State no. 21, item 66).

Dekret Naczelnika Państwa z dnia 16 grudnia 1918 r. w przedmiocie przymusowego zarządu państwowego, Dz. Praw Państwa Polskiego nr 21, poz. 67 (The 16.12. 1918 Chief of State Decree on the Compulsory State Board, The Journal of Laws of the Polish State no. 21, item 67).

Dekret Prezydenta Rzeczypospolitej z dnia 26 kwietnia 1936 r. w sprawie obrotu pieniężnego z zagranicą oraz obrotu zagranicznemi i krajowemi środkami płatniczemi, Dz. U. nr 32, poz. 249 (The 26.04.1936 Chief of State Decree on Money Circulation Abroad as well as the Transfer of Foreign and National Currency, Journal of Laws, no. 32, item 249).

Dekret z 24 marca 1809 r. przyjęcie Kodeksu handlowego, Dz. Praw Księstwa Warszawskiego (The 24.03.1809 Decree on the Adoption of The Commercial Code, the Journal of Law of the Duchy of Warsaw), vol. I, pp. 239-241.

Dekret z dnia 26 sierpnia 1946 r. o zniesieniu izb rolniczych (The 26.08.1946 Decree on Abolition of Chamber of Agriculture, Dz. U. Nr 47, poz. 265 Journal of Laws, no. 47, item 265).

Dekrety Naczelnika Państwa z dnia 4 lutego 1919 r.: o patentach na wynalazki, o ochronie wzorów rysunkowych i modeli, o ochronie znaków towarowych, Dz. Praw Państwa Polskiego nr 13, poz. 137, 138, 139 (The 4.02.1919 Chief of State Decrees on Patents on Inventions, Protection of Illustrated Patterns and Models and Protection of Trade Marks, Journal of Law of the Polish State, no. 13, items $137,138,139)$.

Dniestrzański S., 1932, O istocie prawa gospodarczego, „Czasopismo Prawnicze i Ekonomiczne". 
Dziurzyński T., Fenichel Z., Honzatko M., 1935, Kodeks handlony. Komentary, vol. I, Księgarnia Powszechna, Cracow.

Górnicki L., 2003, Organizacyjne zagadnienia kodyfikacji prawa handlowego w Komisji Kodyfikacyjnej RP (1919-1939), „Acta Universitatis Wratislaviensis” no. 2501, Prawo CCLXXXV, Wrocław.

Górnicki L., 2015, Prace Komisji Kodyfikacyjnej RP nad kodeksem handlonym z.1934 r. organizacja i koncepcja kodyfikacyjna, „Przegląd Prawa Handlowego”, no. 8.

Górnicki L., 2000, Prawo cywilne w pracach Komisji Kodyfikacyjnej Ræecsypospolitej Polskiej w latach 1919-1939, „Kolonia Limited”, Wrocław.

Grabski W., 1927, Dwa lata pracy u podstaw państwowości nas飞ej (1924-1925), F. Hoesick, Warsaw.

Janczewski S., 1948, Prawo gospodarcze jako nauka, „Państwo i Prawo”, books 5-6.

Jastrzębski R., 2014, Dekret walutowy ₹. 1934 r. (Geneza - praktyka - znaczenie), [in:] Miedsy stabilizacja a ekspansja. System finansony w stużbie modernizacii (z. warsztatón badawczych historyków gospodarcsych), J. Lazor, W. Morawski (eds), Gajt, Wrocław.

Jastrzębski R., 2016, Lex Zoll, Zarys prawno-ekonomiczno-historyczny, Wolters Kluwer, Warszawa.

Jastrzębski R., 2014, Polityka oddtużeniowa lat 30. a społeczeństwo Drugiej Ržecsypospolitej, [in:] Metamorfosy spoteczne 8. Państwo i spoteczeństwo Drugiej Rzecsypospolitej. Zbiór studiów, J. Żarnowski (ed.), Instytut Historii PAN, Warsaw.

Jastrzębski R., 2015, Prawo handlowe in statu nascendi II RP - pojecie $i$ ragadnienia kodyfikacyjne, „Przegląd Prawa Handlowego”, no. 5.

Jastrzębski R., 2010, Stabilizacja i wspótczesne funkecje polskiego prawa wekslowego, [in:] Prawo Handlowe XXI wieku. Cras stabilizacji, ewolucji cry rewolucii. Ksiega jubileuszowa Profesora Józefa Okolskiego, M. Modrzejewska (ed.), Wolters Kluwer Polska, Warsaw.

Jastrzębski R., 2009, Wplyw sity nabywczej pieniadza na wykonanie zobowiazan prywatnoprawnych w II Rzeczypospolitej, Wolters Kluwer Polska, Warsaw.

Knakiewicz Z., 1967, Deflacja Polska 1930-1935, Warsaw.

Komisja Kodyfikacyjna Rzecsypospolitej Polskiej, 1922, Dział ogólny, t. I, z. 3, Warsaw 1921, vol. I, book 4, Warsaw 1922, vol. I, book 5, Warsaw.

Konwencja niemiecko-polska dotycząca Górnego Śląska, podpisana w Genewie dnia 15 maja 1922 roku (The German-Polish Convention on Upper Silesia, signed in Geneva on May, 15, 1922), The Journal of Laws, no. 44, item 371.

Kozłowski J., Szawłowski W., 1929, Kodeks Handlowy obowiqzinacy na ziemiach wschodnich, F. Hoesick, Warsaw.

Kraczkowski R., 1994, Dekretowanie ustaw w Polsce w latach 1918-1926, Wydawnictwo Sejmowe, Warsaw.

Landau Z., Tomaszewski J., 1989, Lata interwencjonizmu państwowego 1936-1939. Gospodarka Polski Międsyywojennej 1918-1939, vol. IV, „Ksiażka i Wiedza”, Warsaw.

Landau Z., Tomaszewski J., 1971, Od Grabskiego do Piłsudskiego. Okres kryzysu poinflacyjnego i osymienia koniunktury 1924-1929. Gospodarka Polski Międrywojennej 19181939, vol. II, „Książka i Wiedza”, Warszawa.

Morawski W., 2003, Kronika krysysów gospodarçych, Wydawnictwo TRIO, Warsaw. 
Morawski W., 2008, Od marki do ztotego. Historia finansón Drugiej Ržecsypospolitej, Wydawnictwo Naukowe PWN, Warsaw.

Namitkiewicz J., 1927, O najważniejşyych zasadach badania prawa handlowego, F. Hoesick, Warsaw.

Namitkiewicz J., 1921, Obecny stan prawodawstwa handlowego w b. Królestwie Kongresowem, „Ruch Prawniczy i Ekonomiczny”, book 3.

Namitkiewicz J., 1925, Polska ustawa czeekowa a bespieczeństwo obrotu, „Przegląd Prawa Handlowego".

Niemiecki kodeks handlowy z dnia 10. maja 1897, ₹ uñglednieniem ustaw u₹upetniajacych, 1912, na język polski przełożył i wydał Tadeusz Zborowski radca sądu okręgowego w Inowrocławiu (The German commercial code of May, 10, 1897, taking into consideration the upplementing act, translated into Polish and published by Tadeusz Zborowski, supervisor of the Central Court in Inowroclaw), Poznań.

Podolska-Meducka A., 2003, Polskie ustawodawstwo kartelowe w latach 1918-1939, Wydawnictwo Sejmowe, Warszawa.

Rosenblüth I., 1928, Prawo gospodarcze w Niemczech w r. 1927, „Przegląd Prawa Handlowego", no. 6.

Rozporządzenie Ministra Sprawiedliwości z dnia 1 lipca 1934 r. wydane w porozumieniu z Ministrem Przemysłu i Handlu, a nadto co do $\$ \int 5$, 8, 55, 62, 65-69 i $77 \mathrm{w}$ porozumieniu z Ministrem Skarbu, a co do $\int \$ 60$ i $64 \mathrm{w}$ porozumieniu z Ministrami Komunikacji oraz Poczt i Telegrafów o rejestrze handlowym, (The 1.07.1934 Decree of the Minister of Justice issued in cooperation with the Minister of Industry and Commerce, and furthermore in terms of $\iint 5,8,55,62$, 65-69 and 77 in cooperation with the Minister of Treasury, whereas in terms of $\iint 60$ and 64 in cooperation with the Ministers of Communication, in cooperation with the Ministers of Communication, Post Office and Telegraphs on Commercial Register), The Journal of Laws, no. 59, item 511

Rozporządzenie Prezydenta Rzeczpospolitej z dnia 27 października 1933 r. Kodeks zobowiazzań (The 27.10.1933 Decree of the President of the Republic of Poland, The Code of Obligations), The Journal of Laws, no. 82, item 598.

Rozporządzenie Prezydenta Rzeczypospolitej z 22 marca 1928 r. o ochronie wynalazków, wzorów i znaków towarowych, Dz. U. nr 39, poz. 384 (The 22.03.1928 Decree of the President of the Republic of Poland on the Protection of Inventions, Patterns and Trade Marks), The Journal of Laws, no. 39, item 384.

Rozporządzenie Prezydenta Rzeczypospolitej z dnia 10 grudnia 1924 r. o fuzji (łączeniu się) spółek akcyjnych i spółek z ograniczoną odpowiedzialnością - The 10.12.1924 Decree of the President of the Republic of Poland on Merger (connection) of Stock Companies and Limited Liability Companies, The Journal of Laws, no. 107, item 968.

Rozporządzenie Prezydenta Rzeczypospolitej z dnia 12 czerwca 1934 r. o wierzytelnościach w walutach zagranicznych (The 12.06.1934 Decree of the President of the Republic of Poland on Credibilities in Foreign Currencies), The Journal of Laws, no. 59, item 509. 
Rozporządzenie Prezydenta Rzeczypospolitej z dnia 14 listopada 1924 r. o prawie wekslowem (The 14.11.1924 Decree of the President of the Republic of Poland on the Bill of Exchange Law) The Journal of Laws, no. 100, item 926.

Rozporządzenie Prezydenta Rzeczypospolitej z dnia 14 listopada 1924 r. o prawie czekowem (The 14.11.1924 Decree of the President of the Republic of Poland on the Bill of Cheque Law), The Journal of Laws, no. 100, item 927.

Rozporządzenie Prezydenta Rzeczypospolitej z dnia 14 maja 1924 r. o przerachowaniu zobowiazań prywatno-prawnych (The 14.05.1924 Decree of the President of the Republic of Poland on Miscalculation of Private and Legal Obligations), The Journal of Laws, no 42, item 441.

Rozporządzenie Prezydenta Rzeczypospolitej z dnia 15 lipca 1927 r. o izbach przemysłowo-handlowych (The 15.07.1927 Decree of the President of the Republic of Poland on Chambers of Industry and Commerce), The Journal of Laws, no. 67, item 591; uniform text: The Journal of Laws of 1936, no. 45, item 335.

Rozporządzenie Prezydenta Rzeczypospolitej z dnia 17 marca 1928 r. o prawie bankowem (The 17.03.1928 Decree of the President of the Republic of Poland on the Bank Law), The Journal of Laws, no. 34, item 321.

Rozporządzenie Prezydenta Rzeczypospolitej z dnia 20 stycznia 1924 r. w przedmiocie ustanowienia statutu dla banku emisyjnego (The 20.01.1924 Decree of the President of the Republic of Poland on Establishing Emission Bank Statute), The Journal of Laws, no. 8, item 75.

Rozporządzenie Prezydenta Rzeczypospolitej z dnia 22 marca 1928 r. Prawo o spółkach akcyjnych (The 22.03.1928 Decree of the President of the Republic of Poland), The Journal of Laws, no. 39, item 383.

Rozporządzenie Prezydenta Rzeczypospolitej z dnia 22 marca 1928 r. o izbach rolniczych (The 22.03.1928 Decree of the President of the Republic of Poland on the Chamber of Agriculture), The Journal of Laws, no. 39, item 385; uniform text: The Journal of Laws of 1933, no. 2, item 16.

Rozporządzenie Prezydenta Rzeczypospolitej z dnia 24 października 1934 r. Prawo upadłościowe (The 24.10.1934 Decree of the President of the Republic of Poland. Bankruptcy law), The Journal of Laws, no. 93, item 834.

Rozporządzenie Prezydenta Rzeczypospolitej z dnia 24 października 1934 r. o konwersji i uporządkowaniu długów rolniczych (The 24.10.1934 Decree of the President of the Republic of Poland), The Journal of Laws, no. 94, item 841.

Rozporządzenie Prezydenta Rzeczypospolitej z dnia 26 stycznia 1928 r. o kontroli ubezpieczen (The 26.01.1928 Decree of the President of the Republic of Poland on Insurance Control), The Journal of Laws, no. 9, item 64.

Rozporządzenie Prezydenta Rzeczypospolitej z dnia 27 czerwca 1934 r. Kodeks Handlowy (The 27.06.1934 Decree of the President of the Republic of Poland. Commercial Code), The Journal of Laws, no. 57, item 502.

Rozporządzenie Prezydenta Rzeczypospolitej z dnia 27 czerwca 1934 r. Przepisy Wprowadzające Kodeks Handlowy (The 27.06.1934 Decree of the President of the Republic of Poland. Regulations introducing the Commercial Code), The Journal of Laws, no. 57, item 503. 
Rozporządzenie Prezydenta Rzeczypospolitej z dnia 27 grudnia 1924 r. o warunkach wykonywania czynności bankowych i nadzorze nad temi czynnościami (The 27.12.1924 Decree of the President of the Republic of Poland on the Conditions of Performing Bank Activities and Supervision of These Activities), The Journal of Laws, no. 114, item 1018.

Rozporządzenie Prezydenta Rzeczypospolitej z dnia 27 października 1933 r. Prawo o spółkach z ograniczoną odpowiedzialnościa (The 27.10.1933 Decree of the President of the Republic of Poland. The Law of Limited Liability Companies), The Journal of Laws, no. 82, item 602.

Rozporządzenie Prezydenta Rzeczypospolitej z dnia 27 października 1933 r. o izbach rzemieślniczych i ich zwiazzku (The 27.10.1933 Decree of the President of the Republic of Poland on Chambers of Crafts and Their Association), The Journal of Laws, no. 85, item 638.

Rozporządzenie Prezydenta Rzeczypospolitej z dnia 28 grudnia 1924 r. o organizacji giełd (The 28.12.1924 Decree of the President of the Republic of Poland on the Organization of Stock Markets), The Journal of Laws, no. 114, poz. 1019; uniform text: The Journal of Laws of 1930, no. 23, item 209.

Rozporządzenie Prezydenta Rzeczypospolitej z dnia 28 grudnia 1924 r. o prawie o domach składowych (The 28.12.1924 Decree of the President of the Republic of Poland on the Warehouse Law), The Journal of Laws, no. 114, item 1020.

Rozporządzenie Prezydenta Rzeczypospolitej z dnia 29 czerwca 1924 r. o lichwie pieniężnej (The 29.06.1924 Decree of the President of the Republic of Poland on Money Usury), The Journal of Laws, no. 56, item 574.

Rozporządzenie Prezydenta Rzeczypospolitej z dnia 29 listopada 1930 r. Prawo górnicze (The 29.11.1930 Decree of the President of the Republic of Poland on the Mining Law), The Journal of Laws, no. 85, item 654.

Rozporządzenie Prezydenta Rzeczypospolitej z dnia 7 czerwca 1927 r. o prawie przemysłowym (The 7.06.1927 Decree of the President of the Republic of Poland on the Industrial Law), The Journal of Laws, no. 53, item 468.

Rozporządzenie Prezydenta Rzeczypospolitej z dnia Prawo o postępowaniu układowym (The Decree of the President of the Republic of Poland on the Arrangement Procedure), The Journal of Laws, no. 93, item 836.

Rozporządzenie Prezydenta Rzeczypospolitej z dnia: 23 sierpnia 1932 r. o zapobieganiu skutkom trudności płatniczych w rolnictwie (The 23.08.1932 Decree of the President of the Republic of Poland on Prevention of Difficulties with Payment in Farming), The Journal of Laws, no. 72, item 652.

Rozporządzenie Rady Ministrów z dnia 14 września 1922 r. w przedmiocie organizacji sądownictwa na Spiszu i Orawie i rozciagnięcia na ten obszar mocy obowiązującej niektórych ustaw i rozporządzeń (The 14.09.1922 Cabinet Resolution on the Organization of the Judiciary System in Spisz and Orawa and the Extension of Certain Acts and Decrees on This Area), ), The Journal of Laws, no. 90, item 833.

Rybarski R., 1924, System Ekonomji Politycznej, vol. I, Wydawnictwo Kasy im. Mianowskiego, Warsaw. 
Tomaszewski J., 1961, Stabilizacja waluty w Polsce, Ksiażka i Wiedza, Warsaw.

Ustawa Handlowa wraz ₹ ustawami dodatkowemi w ttómaczeniu Prof. Dra Józefa Rosenblata. Wydanie trzecie z objaśnieniami Prof. Dr. Stanisława Wróblewskiego, vol. 1 Ustawa Handlowa, 1906, Księgarnia Leona Frommera, Cracow.

Ustawa Handlowa wraz ₹ ustawami dodatkowemi w ttómaczeniu Prof. Dra Józefa Rosenblata. Wydanie trzecie z objaśnieniami Prof. Dr. Stanisława Wróblewskiego, vol. II Ustany Dodatkowe, 1917, Księgarnia Leona Frommera, Cracow.

Ustawa Handlowa obowiqaujaca na obszarze Wileñszcryzny i Kresów Wschodnich (Ustaw Torgonyj) t. XI, cz. 2 Zwodu Praw Cesarstwa Rosyjskiego, 1927, opracowali W. Tomczak i A. Goldman przekład z wyd. 1903 r. wraz z konstytucjami z 1910 i 1912 r., printed by M. Tenenbaum, Brześć nad Bugiem.

Ustawa Konstytucyjna z dnia 15 lipca 1920 r. zawierająca statut organiczny Województwa Ślaskiego (The 15.07.1920 Constitution Act including the organic statute of the Silesian Voivodeship), The Journal of Laws, no. 73, item 497.

Ustawa z dnia 1 lipca 1949 r. o zmianie dekretu o zniesieniu izb rolniczych (The 1.07.1949 Act on the Change of the Decree on the Abolition of Chamber of Agriculture), The Journal of Laws, no. 41, item 296.

Ustawa z dnia 11 stycznia 1924 r. o naprawie Skarbu Państwa i reformie walutowej (The 11.01.1924 Act on the Renovation of the State Treasury and Currency Reform), The Journal of Laws, no. 4, item 28.

Ustawa z dnia 11 września 1956 r. o izbach rzemieślniczych i Związku Izb Rzemieślniczych (The 11.09.1956 Act on the Chambers of Crafts and Association of Chamber of Crafts), Dz. U. nr 41, poz. 190.

Ustawa z dnia 14 grudnia 1995 r. o izbach rolniczych (The 14.12.1995 Act on the Chambers of Agriculture), Dz. U. z 1996 r. nr 1, poz. 3.

Ustawa z dnia 15 kwietnia 1932 r. o wyrażeniu zgody Sejmu Śląskiego na wejście w życie na obszarze Województwa Śląskiego ustawy z dnia 2 sierpnia 1926 r. o zwalczeniu nieuczciwej konkurencji (The 15.04.1932 Act on the Silesian Seym Accepting the 2.08.1926 Act on Combating Unfair Competion in the Silesian Voivodeship), Dz. U. R.P., no. 96, item 559.

Ustawa z dnia 15 września 2000 r. Kodeks spółek handlowych (The 15.09.200 Act. The Commercial Companies Code), The Journal of Laws, no. 94, item 1037.

Ustawa z dnia 19 lipca 1939 r. o izbach rzemieślniczych i ich zwiazzku (The 19.07. 1993 Act on the Chambers of Crafts and Their Association), The Journal of Laws, no. 65, item 434.

Ustawa z dnia 2 sierpnia 1926 r. zmieniająca i uzupełniająca Konstytucję Rzeczypospolitej z dnia 17 marca $1921 \mathrm{r}$. (The 2.08.1926 Act that amended and supplemented the 17.03.1921 Constitution of the Republic of Poland) (Dz. U. R.P. Nr 44, poz. 267), The Journal of Laws, no. 78, item 442.

Ustawa z dnia 20 stycznia $1921 \mathrm{r}$. o organizacji giełd w Polsce (The 20.01.1921 Act on Organisation of Stock Exchange in Poland), The Journal of Laws, no. 13, item 71.

Ustawa z dnia 22 marca 1989 r. o rzemiośle (The 22.03.1989 Act on Crafts), The Journal of Laws, no. 17, item. 92. 
Ustawa z dnia 23 grudnia 1988 r. o działalności gospodarczej (The 23.12.1988 Act on the Economic Activity), The Journal of Laws, no. 41, item 324.

Ustawa z dnia 23 marca 1920 r. o nadzorze nad przedsiębiorstwami bankowemi i kantorami wymiany (The 23.03.1920 Act on the Supervision of Bank Companies and the Exchange Office), The Journal of Laws, no. 30, item 175.

Ustawa z dnia 25 lutego $1958 \mathrm{r}$. o uregulowaniu stanu prawnego mienia pozostającego pod zarządem państwowym (The 25.02.1958 Act on Regulating the Legal Position of State-owned Property), The Journal of Laws, no. 11, item 37.

Ustawa z dnia 26 października $1921 \mathrm{r}$. w przedmiocie przepisów prawnych, obowiązujących na obszarze Spisza i Orawy, należącym do Rzeczypospolitej Polskiej (The 26.10.1921 Act on the Legal Regulations in the Areas of Spisz and Orawa Belonging to the Republic of Poland), The Journal of Laws, no. 89, item 657.

Ustawa z dnia 28 lutego 2003 r. Prawo upadłościowe i naprawcze (The Bankruptcy and Restoration Law), The Journal of Laws, no. 60, item 535.

Ustawa z dnia 28 marca 1933 r. o kartelach (The 28.03.1933 Act on Cartels), The Journal of Laws, no. 31, poz. 270.

Ustawa z dnia 29 października 1920 r. o spółdzielniach (The 29.10.1920 Act on the Collectives), The Journal of Laws, no. 111, item 733.

Ustawa z dnia 3 czerwca 1919 r. o komisji kodyfikacyjnej (The 3.06.1919 Act on the Commission of Codification), The Journal of the Laws of the Polish State, no. 44, item 315.

Ustawa z dnia 3 stycznia 1946 r. o przejęciu na własność Państwa podstawowych gałęzi gospodarki narodowej (The 3.01.1946 Act on the Nationalization of the Basic Branches of the National Economy), The Journal of Laws, no. 3, poz. 17.

Ustawa z dnia 30 maja 1989 r. o izbach gospodarczych (The 30.05.1989 Act on the Chambers of Commerce), The Journal of Laws, no. 35, item 195.

Ustawa z dnia 31 lipca 1924 r. o naprawie Skarbu Państwa i poprawie gospodarstwa społecznego (The 31.07.1924 Act on the Renovation of the State Treasury and Improvement of Social Administration), Dz. U. Nr 71, poz. 687.

Ustawa zdnia 5 lutego 1924 r. Ustawa o ochronie wynalazków, wzorów i znaków towarowych (The 5.02.1924 Act on Protection of Inventions, Patterns and Trade Marks), The Journal of Laws, no. 31, item 306.

Ustawa z dnia 7 marca 1950 r. Ustawa o Centralnym Urzędzie Drobnej Wytwórczości (The 7.03.1950 Act on the Central Office of Small-Scale Production), The Journal of Laws, no. 10, item 104.

Ustawa z dnia 8 czerwca 1972 r. o wykonywaniu i organizacji rzemiosła (The 8.06. 1972 Act on the Performance and Organization of Crafts), The Journal of Laws, no. 23, item 164, uniform text: The Journal of Laws, no. 7, item 40

Wrzos K. (in fact, Rosenberg H.), 1933, Oko w oko z krysysem. Reportaż z podróży po Polsce, F. Hoesick, Warsaw.

Wspomnienia Fryderyka Zolla (1865-1948), 2000, opracowała Irena Homola Skapska, Zakamycze, Kraków (Memoirs of Fryderyk Zoll (1865-1948), 2000, elaborated by Irena Homola Skąsska, Zakamycze, Cracow). 